\title{
WORLD RULE OF LAW: THE JURISDICTION OF THE INTERNATIONAL COURT OF JUSTICE*
}

\author{
Wallace McClure†
}

$\mathrm{O}$ NE OF THE fundamental prerequisites of a world community functioning under a regime of law and not of arbitrary power is the possession of a court of plenary jurisdiction. The ordinary conception of a court presupposes a tribunal in which persons or groups of persons-in the world community, a fortiori, states-may seek and obtain redress for the violation of their legal rights. It would fly in the face of even the most elementary ideas of the maintenance of legal order to suggest that the defendant in a judicial proceeding could decide for himself or itself whether the charge will be answered or ignored. The right to sue, one of the most salutary of normal human rights, is inseparable from the right to be sued-and the legal duty to accept suit and abide by the decision of the court. Such institution and such custom

* The beginning of the academic year 1959-60 marks the first anniversary of the establishment of the World Rule of Law Center at Duke University, essentially as a part of its School of Law. This new educational effort is dedicated to both teaching and research. Its Director and staff conducted in the second semester, 1958-59, a seminar for upper-class and graduate law students under the title World Law, justifying the use of this future-invoking term by the immense and rapid development of the law of the world community during the lifetime of men now living, and because of the unsatisfactoriness, from several points of view, of the expressions "international law" and "law of nations." The ideal of a world ruled in accordance with duly-accepted law is the beacon by which the Center strives to guide its work-beamed on doing its bit toward realization. One of its projects now under way is the preparation for publication, early in 1960, of a comprehensive discussion of World Court jurisdiction, with special emphasis upon the efforts of member-states to reserve to themselves the determination of whether an issue is one of domestic, not international, jurisdiction.

This article, for which the writer is alone responsible, deals briefly with the subject of that emphasis. It is the second in a series undertaking to set forth salient underlying prerequisites of world rule of law. The first, McClure, World Rule of Law, appeared in I U. Malaya L. Rev. 58 (1959).

† A.B. 1910, LL.B. 1911, University of Tennessee; A.M. 1915, Ph.D. 1924, Columbia University. Member of the Tennessee bar; Consulting Director, Duke University World Rule of Law Center. Officer, United States Department of State, 1920-51. Author, State Constitution Making (1916), A New American Commercial Policy (1924), World Prosperity (1933), International Executive Agreements (1941), World Legal Order (1960). Contributor to periodicals. 
accepted as law are indispensable if "the general principles of law recognized by civilized nations" are to be as firmly established in the community of nations as in nations worthy to be regarded individually as civilized.

The world legal order as evolved to the present lacks this attribute. Accordingly, it is of the highest category of importance that attention be given to the jurisdiction of the highest judicial tribunal of that order, the United Nations International Court of Justice-the World Court in well-chosen common parlance-particularly the exception from such jurisdiction "ipso facto and without special agreement" of "disputes with regard to matters which are essentially within the domestic jurisdiction of the United States of America as determined by the United States of America." In the spring of 1959, nearly thirteen years after the adoption of the resolution of the United States Senate claiming as of right such ex parte disposition of a case in which the United States might be defendant, a resolution to repeal the words "as determined by the United States of America" was introduced into that body, promptly attracting bipartisan sponsorship. Although fully endorsed by the executive branch of the Government, it still awaited action by the Committee on Foreign Relations when the first session of the Eighty-Sixth Congress adjourned at mid-September, that year.

In the phrase "as determined by the United States of America" lay a great gulf fixed in the jurisprudence of centuries and an unbridged schism in the traditional policy of the United States from the presidency of John Adams to the presidency of Eisenhower, dividing that policy between the rule of law through third-party judgment and the rule of arbitrary ex parte determination of the case by the United States itself.

\section{II}

When Washington was president and Jefferson and Randolph were succeeding secretaries of state, the rule of law characterized public policy. In the first international treaty ${ }^{3}$ of the United States under the Constitution put into operation in 1789 , for the enactment of which Chief Justice John Jay was sent to negotiate with Lord Grenville, representative of Great Britain, provision was made for the peaceful

\footnotetext{
${ }^{2}$ Statute of the International Court of Justice art. 36, para. 2, 59 Stat. ro55 (1945) (emphasis added in last clause) [hereinafter cited as STAT. INT'L CT. JUST.]

${ }^{2}$ S. Res. 94, 86th Cong., Ist Sess. (x959), by Sen. Humphrey, of Minnesota.

8 Stat. I 6 (1794); 2 Miller, Treattes and Other INTERnational Acts of THE UNITED STATES OF AMERICA 245 ( 193 I ).
} 
settlement of current disputes. For those not resolved by the instrument itself, three arbitral commissions were agreed to and set up. They dealt with disputes arising out of boundary uncertainties and two categories of claims. The first tribunal completed its work with good humor and good faith, reaching a lasting settlement. ${ }^{4}$ One of the claims commissions ${ }^{5}$ was set up to effectuate a provision of the treaty of peace ${ }^{6}$ that marked the successful achievement of the membership of the United States in the world community. Composed of five commissioners, two appointed by each government, the fifth chosen by lot, it was subject to the further stipulation of the treaty that three of the commissioners should have power to act as the tribunal, provided one of those named on each side and the fifth one should be present. ${ }^{7}$ When in 1799 they found that many of the awards were going or were likely to go against their contentions, both United States commissioners withdrew, thus depriving the majority of capacity to reach decisions. ${ }^{8}$

It is, of course, no function of this article to appraise the justice of what the majority might have held, but it is obvious that the United States members of the international tribunal exercised a veto the effect of which was to defeat the entire effort to arbitrate the dispute. From these successful and unsuccessful arbitrations at the beginning of United States history, clear lines of development extend to the action of the Committee on Foreign Relations and the variant action of the Senate in 1946-the former accepting without such a reservation the full jurisdiction of the World Court, the other encumbering the declaration of acceptance with the above-described amending reservation designed to enable the United States, in the final analysis, to predetermine the outcome of a case against it by refusing to allow the Court to consider its merits. The obligation accepted, as it were, with the right hand could thus be cast aside by a gesture of the left.

What, then, is the present policy of the people of the United States with respect to international adjudication? Do they really want to do their part to strengthen the rule of law in the world, or do they prefer to reserve what their Senate considered the legal right to evade it so far

This was in 1798. See I MOORE, International ARbitration I-43 (1898).

IId. at $45-64$.

- 8 Stat. 80 (1794); 2 Miller, op. cit. supra note 3, at I5 I. See Ware v. Hylton, 3 U.S. (3 Dallas) 199 (1796).

"The other claims commission, not discussed here, was sinilarly constructed. It was able to reach decisions in a considerable number of cases.

${ }^{8}$ The matter was eventually settled by treaty. 8 Stat. 196 (1802); 2 MiLLER, op. cit. supra note 3 , at 488 . 
as their membership in the United Nations and their obligations under the Statute of the World Court are concerned? They cannot do both, for the legal norm nemo judex in re sua is inseparable from the conception of law and of the rule of law. If and when the resolution pending in the Senate is voted upon, the opportunity will come again, as it has come from time to time in the past century and a half, to posit an indication of their answer to this question.

III

Roots of the opposing and mutually inconsistent policies, between which choice has intermittently been expressed, penetrate deep into legal and political philosophy. In the seventeenth century of Christendomthe century of Jamestown and Plymouth Rock-the struggle between democracy and absolutism in the new monarchical nation-states of the European international community that had succeeded less rigorous regimes of preceding eras began to reach the decisive show-down stage. So desperate had been the need for order under law that philosophers like Bodin, ${ }^{9}$ while affirming the amenability of national rulers to international law as then understood, had urged internal absolutism, centralized in the person of the head of state, as the surest means of attaining and preserving order in national communities. $\mathrm{He}$ and other philosophers, seeking to imbue secular rulers with the authority formerly inhering in the head of the predominant Christian church, essayed to indoctrinate men with the ancient notion of the divine right of kings. This, in the teachings of later philosophers, became nonliability of the state to any law. The latter tenet survived internal absolutism and preserved external anarchy.

The dichotomy between those philosophically-expounded pathways which purposefully led to international order and those which necessarily led to international disorder could hardly have been more pointedly illustrated than in the contemporary philosophies of Grotius ${ }^{10}$ and Hobbes. ${ }^{11}$ The former, a man whose name has become a symbol of law in the world community, plead for obedience by the rulers of nation-states to universal law, which to him included the optimum of reason as embodied in the wisdom of the ages. The latter, an upholder of the Stuart kings' claims to absolutism, asserted, "It is not wisdom but authority that makes a law"; but he could find, as Professor

\footnotetext{
${ }^{\circ}$ Bodin, De la Republique (1576); De Republica (1586). See Figgis, The Divine RIGHT OF KINGS 126 (2d ed. 1922).

${ }^{10}$ Grotius, De Jure Belli ac Pacts (1625).

11 HobBes, LeViathan (1651).
} 
McIlwain says, "12 "no better way to give a de jure character to his potestas [authority to make laws] than the unhistorical compact"-an imaginary transaction whereby the people as individuals were averred to have irrevocably contracted away their natural liberty to an absolute monarch hoping thus to gain security in orderly community life.

The idea of le contrat social, like that of divine right, has come down from antiquity and has assumed various forms, not all of them intended to uphold dictatorship, for the compact might be by the people of the nation with one another, not with a single strong man in command. The late seventeenth century version of Locke ${ }^{13}$ and the most famous of all, that of Rousseau ${ }^{14}$ (late eighteenth century), were susceptible of use in support of the English and French revolutions directed toward popular government. But whatever the form or impact of the contract notion, its tendency was to substantiate the finality of the national community and to make more difficult-if not impossiblein the world community the very order that was its objective for the national communities. It has, no doubt, played its part in producing the anomaly of popularly governed nation-states generally little if any less disposed than autocracies to accept the prerequisites of world legal order-witness the identical attitude of "great powers" at San Francisco toward the unanimity rule for the permanent members of the Security Council of the United Nations.

In the philosophy of Hegel, ${ }^{15}$ who lived and wrote in the epoch of the Napoleonic wars, the final dissolution of the Holy Roman Empire, and the overwhelming of the states of his native Germany-the philosophy which more than a century later was to contribute effectively to the intellectual defense of the National Socialism of the Hitler regime-the theory of the deification of the state may be said to have reached its zenith. The idea of national "sovereignty" in the French revolutionary sense of the "sovereignty" of the people was developed in Hegel's imagination into a mystical concept in which the thesis of the natural rights of the individual human being and the antithesis of indispensable communal organization became the synthesis of the nation personified in the divinely ruling head of state.

Hardly less mystical than the Hegelian effort at rationalization and equally untenable as even a philosophers' justification of legal authority

\footnotetext{
${ }^{12}$ Mcilwain, Constitutionalism and the Changing Worid 27 (1939).

${ }^{13}$ Locke, Of Civil Government, Two Treatises of Government (1690).

${ }^{14}$ Rousseau, Du Contrat Social (1762).

${ }^{15}$ Hegel, Grundinien der Philosophie des Rechts (1821) [Elements of THE PHILOSOPHY OF RIGHT (Knox transl. 1942).]
} 
for a man's or a state's arrogation of finality of exclusive right of rulership and law-making, the contract myth maintained no standing in nineteenth-century ideology. But the absolutist theories of the state to which it had given sustenance remained. In place of ancient dogmas, wholly secular "realism" had begun to characterize Western European and North American jurisprudence. Outstanding has been the analytical positivist school of writers who seek to base their systems of legal and political philosophy upon searching examination of the state as it actually exists and functions in the world as they have found it. ${ }^{16}$ In that world, the more powerful states, at least, have claimed each to be final law unto itself. Accordingly, theirs is essentially a philosophy of power politics ${ }^{17}$ rather than of law, ${ }^{18}$ for in the final analysis, a claim in human affairs, to be above law makes sense only if accompanied by a demonstration of power to defy the law. ${ }^{19}$ An analysis of nationstates of the past century and a half would seem to confirm this conclusion. To the analytical positivists, the law is essentially the expressed will or command of the possessor of the law-making potestas. The present-day possessors of such authority backed by power are the more powerful of the eighty to ninety states that make up the world community. As the repositories of power, they are in a position to claim that might makes right and so to claim the right to be answerable to no law that as nation-states they do not choose to obey.

But it remains possible that they may choose to obey, that as members of the world community they may enact effective community law that to abide by the law shall be compulsory, and that they may create community institutions to see that abiding by the law is certainly brought about and maintained.

Speaking for the Supreme Court of the United States in 1907 and referring by citation to Bodin and Hobbes in a case involving the

${ }^{10}$ E.g., AUSTin, LeCtures on JURISPRUdence (1861-1863). See also WilloughbY, an Examination of the Nature of the State (1906; 1911 ); The Fundamental CONCEPTS OF PUBlic LaW (1924).

${ }^{17}$ It is interesting to note that what is called the "Juristic Conception of the State" emanates from writers of this school.

${ }^{18}$ Judge de Visscher has pointed out that existing rules of international law relating to the status asserted for themselves by nation states "largely represent in themselves a compromise between law and power." DE VISSCHER, THEORIÉs ET RÉalITIÉs EN DROIT International Public (1953) [Theory and Reality in Public International LAW 354 (Corbett transl. 1957)].

${ }^{10}$ In a recent article dealing with law, politics, and international disputes, a former officer of the United States Department of State asserted that, under certain named circumstances, "the United States would simply have to defy a Court decision." 5 I6 INTERNational Conciliation $3 \times 2$ (1958). Why "have to," "simply" or otherwise? 
"sovereignty" of the territory of Hawaii, Justice Holmes remarked: "A sovereign is exempt from suit not because of any formal conception or obsolete theory, but on the logical and practical ground that there can be no legal right as against the authority that makes the law on which the right depends."20 Whether or not this aspect of the claim to be above the law is, indeed, one of indubitable logic or exemplary practice, and, especially whether or not it has any relationship to the amenability of a state to world law, it is characteristic of the attitude of those who oppose acceptance of the third-party judgment of the World Court in disputes between their own and other nations, such position being equivalent to a claim that the state is above any law. Internally, states now usually permit suits against themselves. If there is to be the rule of law internationally, they must permit such suits in the International Court of Justice.

The principal utility of legal philosophers is to bring forth and systematize ideas which may informally help judges and legislators in their public tasks. However varying the implications of the doctrines they formulate, and whether or not they are influential with those who actually participate in interpretation and enactment of law, they have all thought and written under decisive influence of the times and circumstances of their lives, usually with earnest desire to ameliorate conditions with which they were personally familiar. They have not and could not have spoken in a manner likely to give useful guidance in all later times. The jurisprudence they have helped to evolve must ever be in process of change to meet the needs of succeeding years and eras.

\section{IV}

In his exceedingly useful little book, The Constitution and World Organization (1944), ${ }^{21}$ Professor Corwin speaks of "three possible conceptions" of what he calls "national sovereignty," of the first of which he says that "sovereignty" may be regarded

... as a concept of International Law and hence as limited by the obligations which that law imposes upon members of the Family of Nations, including the obligation to observe their contractual engagements with one another.

This concept, he says, possesses "very impressive historical support ..."; it asserts, he adds, that

\footnotetext{
${ }^{20}$ Kawananakoa v. Polyblank, 205 U.S. 349, 353 (1907).

${ }^{21} \mathrm{Pp}$. 1-3. Professor Corwin does not support this theory.
} 
International Law itself imposes certain limits on the sovereignty, and hence on the freedom of action of members of the Family of Nations, and that every nation upon its entrance into the Family of Nations consents to be bound by those limits and continues thus bound so long as it remains a member of the Family of Nations. Such limits are accordingly essential ingredients of each nation's sovereignty-sovereignty, in short, exists within International Law and the international order, not outside and above them; it is the obverse of international obligation.

"That this was the theory most generally held by the founders of our own nation," Professor Corwin affirms, "is not open to question." Striking evidence of the correctness of this assertion is found in a statement in The Federalist by the man who was to become first chief justice of the United States. Certain opponents of the Constitution, he tells us, ${ }^{22}$

... though content that treaties should be made in the mode proposed, are averse to their being the supreme law of the land. They insist, and profess to believe, that treaties, like acts of assembly, should be repealable at pleasure. This idea seems to be new and peculiar to this country, but new errors, as well as new truths, often appear. These gentlemen would do well to reflect, that a treaty is only another name for a bargain; and that it would be impossible to find a nation who would make any bargain with us, which should be binding on them absolutely, but on us only so long and so far as we may think proper to be bound by it. They who make laws, may without doubt, amend or repeal them, and it will not be disputed that they who make treaties, may alter or cancel them; but still let us not forget, that treaties are made not by one only of the contracting parties, but by both; and consequently, that as the consent of both was essential to their formation at first, so must it ever afterwards be to alter or cancel them. The proposed Constitution, therefore, has not in the least extended the obligation of treaties. They are just as binding, and just as far beyond the lawful reach of legislative acts now, as they will be at any future period, or under any form of government.

Despite the common sense and respect for law that mark this utterance, the "new errors" persisted and have become old. Their presence with regard to what is now often called (correctly) international legislation, no less than with regard to international adjudication, shows identity of attitude in the determination of their adherents to keep the

\footnotetext{
${ }^{22}$ No. 64 , at 487 (Hamilton ed. 1866 ) (Jay). The Constitution reference is to art. VI, declaring treaties to be "the supreme Law of the Land." See Chief Justice Jay's charge to the jury in Georgia v. Brailsford, 3 U.S. (3 Dallas) x, 3-5 (1794). See also Ware v. Hylton, 3 U.S. ( 3 Dallas) I99 (1796); United States v. The Schooner Peggy, 5 U.S. (I Cranch) 103 (1801).
} 
nation unresponsive to ever-growing, ever-more-pressing need in the world as it is. In both phases of the common problem, the people of the United States are confronted with opportunity so to develop their policy as to build for themselves and their fellow peoples a higher degree of safety by strengthening world legal order. The re-examination of the relation of the United States with the World Court, recommended by President Eisenhower in his State of the Union message, I $959,{ }^{23}$ must now be considered.

Such re-examination could profitably range over much history and take several mutually complementary directions. For present purposes, it must be confined rather closely to the essentials of the relevant provision of the Court's Statute and the circumstances surrounding the adoption of the words "as determined by the United States" in the declaration of acceptance of the jurisdiction of the International Court of Justice provided for in article $36(2-6)$.

\section{V}

On August 26, I946, the following declaration on the part of the United States, dated August I4, I946, was deposited with the SecretaryGeneral of the United Nations: ${ }^{24}$

I, Harry S. Truman, President of the United States of America, declare on behalf of the United States of America, under Article 36, paragraph 2, of the Statute of the International Court of Justice, and in accordance with the Resolution of August 2, 1946, of the Senate of the United States of America (two-thirds of the Senators present concurring therein), that the United States of America recognizes as compulsory ipso facto and without special agreement, in relation to any other state accepting the same obligation, the jurisdiction of the International Court of Justice in all legal disputes hereafter arising concerning

a. the interpretation of a treaty;

b. any question of international law;

${ }^{23} 105$ Cong. Rec. 167 (daily ed. Jan. 9, 1959).

${ }^{21} 61$ Stat. 1218, 1 U.N.T.S. 9 (1946) (emphasis added). Paragraphs 3 and 5 of art. 36 , of the Statute of the International Court of Justice, are as follows:

" 3 . The declarations referred to above may be made unconditionally or on condition of reciprocity on the part of several or certain states, or for a certain time."

-...

"5. Declarations made under Article 36 of the Statute of the Permanent Court of International Justice and which are still in force shall be deemed, as between the parties to the present Statute, to be acceptances of the compulsory jurisdiction of the International Court of Justice for the period which they shall have to run and in accordance with their terms." 
c. the existence of any fact which, if established, would constitute a breach of an international obligation;

d. the nature or extent of the reparation to be made for the breach of an international obligation;

Provided, that this declaration shall not apply to

a. disputes the solution of which the parties shall entrust to other tribunals by virtue of agreements already in existence or which may be concluded in the future; or

b. disputes with regard to matters which are essentially within the domestic jurisdiction of the United States of America as determined by the United States of America; ${ }^{25}$ or

c. disputes arising under a multilateral treaty, unless (I) all parties to the treaty affected by the decision are also parties to the case before the Court, or (2) the United States of America specially agrees to jurisdiction; ${ }^{26}$ and

Provided further, that this declaration shall remain in force for a period of five years and thereafter until the expiration of six months after notice may be given to terminate this declaration.

The inconsistency between the italicized words "recognizes as compulsory" and the italicized reservation " $b$ " is hardly less than that between the latter and paragraph six of article thirty-six of the Statute:

In the event of a dispute as to whether the Court has jurisdiction, the matter shall be settled by the decision of the Court.

"As determined by" itself, accordingly, presents not only an internal contradiction in the United States declaration of acceptance, but is

${ }^{25}$ The United States Senate appears to be the originator of this formula. Since then, half a dozen other states have made equivalent reservations. Those of France and of the United States were considered, respectively, by the World Court in the Norwegian Loans case, [1957] I.C.J. Rep. 9; and the Interhandel case, [1957] I.C.J. Rep. 105 (interin measures), [1959] I.C.J. Rep. 6 (preliminary objections). See notes 4I $\& 42$ infra. In the former, France, suing Norway, which had accepted the jurisdiction of the Court under art. $36(2)$ without any comparable reservation, found itself confronted by a ruling of the Court that under the reciprocity provisions of the article, France's reservation entitled Norway to deny the Court's jurisdiction on the ground that the subject of the adjudication was domestic as understood by Norway. France thus lost its case. On July Io, 1959, France filed a new declaration of acceptance making exception of disputes "relating to questions which by international law fall exclusively within the domestic jurisdiction" (translation from French; emphasis added); on September 14, 1959, India, which had previously terminated its declaration of acceptance of jurisdiction under art. $36(2)$, filed a new declaration excepting disputes relating to matters essentially within its jurisdiction, but did not include the further reservation of determination by itself.

${ }^{39}$ Like the last clause of reservation (b), this obscure and obstructive reservation (c) should be elininated from the United States declaration. Discussion of (c) is, however, outside the scope of this article. 
obviously in direct conflict with a positive requirement of the basic law of the Court, the Statute, part of the Charter of the United Nations which the United States had, a year before, accepted, wholly without any kind of reservation, with only two senators voting against it.

It would seem to follow that the reservation to the declaration must be pronounced to be an attempt not only to be in a position to prevent the Court from performing the normal function of courts, but to do so in violation of a provision of a treaty to which the United States was at the time party and which, under its Constitution, it had made the law of the land. The treaty thus violated contained another highly relevant provision: ${ }^{27}$

In the event of a conflict between the obligations of the Members of the United Nations under the present Charter and their obligations under any other international agreement, their obligations under the present Charter shall prevail.

To depart, by a mere unilateral act like the reservation, from law as contained in a provision of a treaty to which the United States had joined the greater part of the nations of the world in according such primacy is, indeed, a far, far cry from the counsel of the man who became its first chief justice after he had written, "let us not forget, that treaties are made not by one only of the contracting parties, but by both; and consequently, that as the consent of both was essential to their formation at first, so much it ever afterwards be to alter or cancel them.”28 This is inescapably a matter not only of law and policy, but one affecting the good faith, the national honor, of the people of the United States.

\section{VI}

"National honor" is a phrase that used to appear in arbitration treaties to which the United States was a party. In the early days, when that comparatively primitive form of effort to achieve international adjudication was looked upon with the same fearsomeness that gripped the Senate when it overrode the counsel of its Committee on Foreign Relations and superadded the reservation "as determined by" the United States, arbitration treaties often excepted from the obligation to arbitrate matters affecting "the vital interests, the independence, or the honor ${ }^{329}$ of the states parties. It may be passing strange that

\footnotetext{
${ }^{27}$ U.N. ChaRTER art. I03.

${ }^{28}$ The Federalist, No. 64, at 488 (Hamilton ed. 1866 ) (Jay).

${ }^{29}$ E.g., art. 1 of Convention between the United States and France for settlement of disputes by arbitration, 35 Stat. 1925 (1908), I01 BR. AND FOR. ST. PAPERs rorg (xg08).
} 
honor, here deemed so sacred as to be above arbitral consideration, should be so cavalierly treated by the Senate on other occasions, but the point here to be emphasized is of another kind. Vague inclusive phrases, like the one quoted from treaties of half a century ago, effectually liquidate obligation to refer disputes to the arbitral court. So the arbitration treaties enacted prior to World War $I_{3}$ contemplating resort to the Permanent Court of Arbitration of the general convention of the Hague for the pacific settlement of international disputes, were unsatisfactory; and it was with a view to tightening the obligation to arbitrate that in the large group of treaties enacted around 1930, such exception was omitted and, as principal exception, was stipulated subject matter "within the domestic jurisdiction of either of the High Contracting Parties."30 In no case was "as determined by" the parties themselves added; on the other hand, records of the negotiations which preceded enactment not only fail to give reliable evidence of such intent, but indicate the intended criterion of determination according to international law. ${ }^{31}$ Determination by itself, with finality, of the meaning of a rule of international law binding upon other states, does not appear to have been claimed by any state even though claiming for itself the right to be above that law. ${ }^{32}$

\footnotetext{
${ }^{80}$ E.g., Arbitration and conciliation treaty between the United States and Switzerland, 47 Stat. I 983 , I29 L.N.T.S. 465 (1932).

${ }^{31}$ See Briggs, Towards the Rule of Law?, 5x AM. J. INT'L L. 517, 525-27 (1957). Professor Briggs position, based chiefly on the record of negotiation of the arbitration treaty between the United States and Belgium, rog L.N.T.S. 269, 46 Stat. 2790 (1930), art. II(a) of which contains a provision identical with that quoted, is challenged with some cogency, but in the opinion of the present writer inconclusively, by Professor Sidney B. Jacoby, formerly of the United States Department of Justice, in Towards the Rule of Law?, 52 AM. J. INT'L 107 (1958). In 1958, Professor Briggs delivered a course of lectures before the Academy of International Law at The Hague. See Briggs, Reservations to the Acceptance of Compulsory Jurisdiction of the International Court of Justice, 70 HAGUE RECUEIL 225 (1958).

${ }^{32}$ In this general connection, a passage of Judge de Visscher, op. cit. supra note I 8 , at 347 , is of interest. He says that "the form recently given by some States to the reservation excluding compulsory jurisdiction of disputes relating to internal affairs or 'matters which are essentially within the domestic jurisdiction' marks a retreat to earlier practice. Before the second world war, none of the States making a reservation of this kind had claimed the right to decide by itself and without appeal the question of its legitimate application. The texts of the period, modelled at once on Article r5, paragraph 8, of the Covenant of the League of Nations, and on Article 39 of the Geneva General Act, r928, explicitly referred the question whether or not a dispute related to a matter within 'the exclusive jurisdiction of the State' to international law, interpreted, in case of debate, by the Court. This solution favored progress in international law since it opened the way for the rules of that law into questions left until then to the discretion of the State."
} 
Between the mid-thirties and mid-forties of the twentieth century, the general world policy of the United States underwent a fundamental change of unprecedentedly immense significance. Even current phrases like the Congress-dictated "neutrality" acts and the Senate-inflicted defeat of the World Court (notwithstanding noninclusiveness of jurisdiction without special agreement) became as irrelevant to an appraisal of that policy as the language of the pre-World War I arbitration treaties. World War II had taught its cataclysmic lessons. In its wake, the United States had not only led the movement for, but had become party to, the Charter of the United Nations, of which the World Court statute was an integral part, and the Court had become the "principal judicial organ"33 of the United Nations. In reporting the Charter and Statute to the Senate, the Foreign Relations Committee called attention to a recommendation of a commission of the San Francisco Conference that members of the United Nations should proceed as soon as possible to make declarations of acceptance of the jurisdiction of the Court without special agreement. And it had added the caveat: "Unless we are prepared to take all steps which are necessary to effectuate our membership in the United Nations we would be merely deceiving the hopes of the United States and humanity in ratifying the Charter."34

Although a resolution for such acceptance was introduced into the Senate almost immediately, more than a year passed before action was taken. In a report of admirable perceptivity and clarity, ${ }^{36}$ the Foreign Relations Committee unanimously recommended excepting from the application of the declaration "disputes with regard to matters which are essentially within the domestic jurisdiction of the United States." Such exception the Committee felt to be in principle "implicit in the nature of international Law," which, under its Statute, it is the duty of the Court to apply. "International Law," continued the Committee, is, by definition, the body of rights and duties governing states in their relations with each other and does not, therefore, concern itself with matters of domestic jurisdiction. The question of what is properly a matter of international law is, in case of dispute, appropriate for decision by the Court itself, since, if it were left to the decision of each individual state, it would be pos-

\footnotetext{
${ }^{88}$ U.N. Charter art. 92; STAT. INTL CT. JUST, art. I.

${ }^{34}$ Quoted by Professor Philip C. Jessup in the Hearings on S. Res. rg6 before a Subcommittee of the Senate Committee on Foreign Relations, 7gth Cong., 2d Sess. 147 (1946).

${ }^{35}$ S. Rep. No. 1835,79 th Cong., 2 d Sess. 2, 5 (1946). See STAT. INT'L CT. JUST. art. $38(x)$.
} 
sible to withhold any case from adjudication on the plea that it is a matter of domestic jurisdiction.

Thus, the Committee demonstrated its complete understanding of what it was recommending. It may be confidently assumed that no one has ever hinted that in line with some vague allegation of tradition or policy omission of the words "as determined by the United States" nevertheless left such determination to the United States. Other states reserving "matters of domestic jurisdiction" had in no case expressly reserved to themselves the right of decision. The Committee had unreservedly concluded

... that a reservation of the right of decision as to what are matters essentially within domestic jurisdiction would tend to defeat the purposes which it is hoped to achieve by means of the proposed declaration as well as the purpose of article 36 , paragraphs 2 and 6 , of the Statute of the Court.

Clinching its argument, the Committee pointed out: ${ }^{36}$

The United States has now become a member of the Court, but membership in itself means comparatively little. It is true that states can agree to submit specified cases to the Court, but they have always been able to settle their disputes by arbitration, assuming they could agree to do so. So long as individual members can refuse to be haled into the Court a regime of law in the international community will never be realized. The most important attribute of this or any other court is to hear and decide cases. For this function it must have jurisdiction of the parties and the subject matter. out,

"The ultimate purpose of the resolution," the Committee pointed is to lead to general world-wide acceptance of the jurisdiction of the International Court of Justice in legal cases. The accomplishment of this result would, in a substantial sense, place international relations on a legal basis, in contrast to the present situation, in which states may be their own judge of the law.

But there remained the vote of the Senate.

\section{VII}

The tragedy of that vote, the results of which have been set forth above, is in no sense lessened by the possibility that some of its implications may not have been fully understood by all of those whose votes determined the issue. Some six weeks previously, a subcommittee of

\footnotetext{
${ }^{30}$ S. REP. No. I 835 , 79th Cong. 2d Sess. 3 (1946).
} 
the Foreign Relations Committee held hearings on the proposed resolution, during the course of which the following dialogue occurred between one of the members of the subcommittee and the Senator who had introduced the Resolution: $:^{37}$

Senator AUSTIN. How much of a restriction would you regard the insertion of certain words in that clause " $b$," relating to who decides that question of what is domestic jurisdiction-that is, would you regard it as nullifying your purpose, if you inserted into this phrase, "disputes with regard to matters which are essentially within the domestic jurisdiction of the United States," which would make it read:

disputes which are held by the United States to be with regard to matters which are essentially within the domestic jurisdiction of the United States?

Senator MORSE. I would accept the language.

Senator AUSTIN. You would?

Senator MORSE. I would accept the language.

Senator AUSTIN. Otherwise, I foresee the conflict that naturally would arise over such questions as immigration, the interpretation of a treaty for example with respect to the immigration of orientals.

Senator MORSE. I would accept the language as of now.

Senator AUSTIN. Yes.

The apparently astonished "You would?" seems significant. Senator Morse had some eloquent words for the subcommittee-"that the only hope of our survival as a nation, and the only hope of a survival of the peoples of the world . . . is to be found in the development of an ever stronger and stronger international organization"-and he ably combatted in the debate in the Senate ${ }^{38}$ and cast his vote against the amendment so ominously adumbrated in Senator Austin's query. But those who, whatever their purpose, or their lack of purpose, acted to make international organization and the World Court weaker, carried the day overwhelmingly.

\section{VIII}

So what was excepted is "the domestic jurisdiction of the United States of America as determined by the United States of America": A mighty utterance indeed! but what does it mean? How, for instance, does the United States of America determine what is within the domestic jurisdiction of the United States of America? In these days of

${ }^{37}$ Hearings, supra note 34 , at 36 .

${ }^{38} 92$ Cong. REc. 10629-31 (1946); also, especially, id. at xo695, c. 2. But see, id. at $10683-84$. For the vote on the Connally amendment, see $i d$. at 10697; on the resolution of acceptance, see $i d$. at ro705-06; for text as adopted, see $i d$. at 10706 . 
seemingly near approach of interplanetary travel within the narrow confines of that atom of the universe, the solar system, the long-awaited man from Mars may be already on his way. So oracular are the words of the reservation that, if democratically-minded, he might assume a national plebiscite or, failing that, a joint-resolution of Congress or a Senate resolution (two-thirds of the Senators present concurring therein). Learning a bit of the political philosophy inhering in this minor fraction of the little globe on which he had alighted, the Martian might quite conceivably conclude that the decision would be taken by that department of the tripartite government in which the "judicial Power of the United States" is vested, ${ }^{39}$ presumably the "one Supreme Court"; for surely what is essentially within jurisdiction, domestic or otherwise, is essentially a judicial question. But some denizen of earth might whisper the oft-quoted words of the man who became the great chief justice: "The President is the sole organ of the nation in its external relations. ..."40 To which the astonished space-traveler quite likely would reply: "External? but is there not available the jurisdiction of a Court of your own little world community? Are not your people among the signers of its constitution? Is it not a part of your own national governmental setup, extended? In short, is it not your Court?"”

Precisely how the determination by the United States of its domestic jurisdiction was, in the contemplation of the authors of the reservation, to be determined appears to have been little discussed. Is the President supposed to render a considered decision? Presumably he could successfully assert authority to do so. Could or should the Congress enact legislation requiring him to do so?-in which event, by what subordinate would the determination in fact essentially be made? In case the Departments of State and Justice should disagree, which would prevail? What actually was the procedure in the famous Interhandel case? ${ }^{41}$ Maybe the man from Mars might be employed as a researcher

${ }^{30}$ U.S. Const, art. III, $\$$ r.

${ }^{60}$ Quoted in United States v. Curtiss-Wright Export Corp., 299 U.S. 304, 319 (1936). Lawrence Preuss, 32 A.B.A.J. 66I (1946), takes it for granted that "the President alone" will determine whether a dispute involves matters essentially within U.S. domestic jurisdiction.

${ }^{42}$ A review of this World Court case appears in this issue of the Journal, infra at 73. See also supra note 25 . The Institute of International Law, meeting at Neuchatel, Switzerland, adopted on Sept. 11, 1959, resolutions in part as follows:

"In an international community the members of which have renounced recourse to force and undertaken by the Charter of the United Nations to settle their international disputes by peaceful means in such a manner that international peace and security, and justice, are not endangered, recourse to the International Court of Justice or to another international court or arbitral tribunal constitutes a normal inethod of settlement of 
to ascertain just where in the civil service hierarchy essentially domestic jurisdiction has been or is most likely hereafter to be essentially determined.

As for the people of the United States, it would seem in the highest sense essential to determine whether it is safer or more enlightened to leave such determination to nonjudicial officialdom, or to their World Court. It is undeniable that the World Court is a part of the governmental apparatus that belongs to the people of the United States. It is theirs for use, service, and support. It was created through collaboration of their treaty-making power. It is required by the most solemn and effectual of international constitutional law to decide all cases before it, whether or not involving jurisdiction, in accordance with recognized rules of law. One of the fully-recognized rules of world law is that domestic questions must be left to national jurisdiction. The history of the Court is a conclusive demonstration of its conscientious judicial conservatism.

The most basic political conservatism in the world today is that which promotes the development of legal order in the world community. To strengthen the Court by eliminating vetoes to the performance of its judicial duties is one of the most fruitful means to this end. France and India have removed from their acceptance of the Court's jurisdiction their reservations as determined by themselves, in originally making which they followed the example of the United States. ${ }^{42}$ Nothing could be more fitting than for the United States to follow their genuinely emulatory reverse action. To do so would be to get back on the road of human progress.

legal disputes as defined in Article 36, paragraph 2, of the Statute of the International Court of Justice. ... .

"It is highly desirable that States having excluded from their acceptance of the compulsory jurisdiction of the International Court of Justice in virtue of Article 36, paragraph 2, of the Statute of the Court matters which are essentially within their domestic jurisdiction as determined by their own government, or having made similar reservations, should withdraw such reservations having regard to the judgments given and opinions expressed in the Norwegian Loans and Interhandel cases and to the risk to which they expose themselves that other States may invoke such reservations against them."

2 The texts in English of the French and Indian declarations, dated respectively July ro and September 14, 1959, appear in this issue of the Journal, infra at 84. 